\title{
Sundry Notes from West Somerset and Devon
}

\section{W. Whistler}

To cite this article: C. W. Whistler (1908) Sundry Notes from West Somerset and Devon, Folklore, 19:1, 88-91, DOI: 10.1080/0015587X.1908.9719813

To link to this article: http://dx.doi.org/10.1080/0015587X.1908.9719813

册 Published online: 14 Feb 2012.

Submit your article to this journal

Џ Article views: 1

Q View related articles $₫$ 
shell, may also be seen. The horse's tooth, the horse-shoe, and the coin, are no doubt generally lucky. As to the shell, A. R. says her grandfather told her it was to prevent its owner from being drowned. Personally I have always imagined that, originally at least, it was a love-charm. The Cypraide and shells of similar form are used in love-magic in some parts of Europe.

Mabel. Peacock.

Sundry Notes from West Somerset and Devon.

THE belief in "overlooking" and witchcraft generally does not pass away, though no special forms have come under my notice. Some five and twenty years ago a "hammer and nail" charm against overlooking was used by an old woman living near Combwich. The then vicar was scandalised to see the old lady hammering a large nail into the footprint of another woman who had just passed down the lane, and was informed that the maker of the footprint had overlooked the operator, and that this proceeding would counteract the spell.

An old woman living on Farringdon Hill up to a few years ago was always credited with uncanny powers, and it was said to be usual for horses to misbehave when passing near her cottage. She also overlooked the moving from one cottage to another of a neighbour, with the result that almost immediately after she had passed the door a dresser full of china, carefully set in place, overbalanced and fell. .

This firm belief in overlooking, I may add, is one with which the village doctor has to reckon, as the belief by a nervous patient that she is being so treated has an immensely retarding effect on a possible recovery.

In the matter of folk-medicine, Taunton Museum preserves two specimens of young ash-trees split for the purpose of passing children suffering from congenital hernia through, one having been used within the last twenty years.

A wych-elm by the road close to Cannington Park was made into a "shrew-tree" not more than six years ago, the scar 
being still visible, by the shepherd then living in a near cottage whose child had infantile paralysis. A hole was bored with an inch auger into the heart of the trunk, and a live shrew-mouse imprisoned in the hole with a solid plug. The idea is that the passage of a shrew-mouse across the affected limb of the infant has been the cause of the paralysis, and that a decoction of the twigs of the tree which has caused the death of the mouse will act as a remedy.

Some malign power of a similar kind is attributed to the common slow-worm. A man in my own employ has told me that his foot turned quite brown after the reptile crawled over it. The local witch will also use the slow-worm in the concoction of a broth for the cure of warts, applying it with a formula in which the Name of the Trinity is invoked.

The potato, carried until it gets hard in the pocket of the patient, is firmly believed in as a cure for rheumatism. It is supposed to "draw the iron out of the blood": too much iron, and consequent stiffness, being the root of the complaint.

A charm against hærnorrhage from Black Torrington in North Devon, may be worth recording. In this case there is no attempt at the usual secrecy, the user of the charm being proud of his occult power, and by no means making profit of it $\mathrm{He}$ is a small farmer of the district, and claims to be the last person by whom the charm can be effectively used, as it can only be handed on by a woman who herself has the power of "stenting blood" by its use. It came to him from such a wise woman, and, so far as he knows, he is the only person to whom she transmitted the gift, while of course he is unable to hand it on.

The charm itself consists in repeating the verse Ezekiel xvi. 6 (q.v.). It is to some extent apposite, being a direct command to an individual suffering from hæmorrhage to "live," though with no command to the blood itself. Whether this may not be a Christianised version of some older formula I cannot venture to say, but it is likely. The descent of the "stenting" power in the female line alone is remarkable. The context of the verse may possibly imply that it was originally used by women only, and on certain emergencies; but this does not 
seem probable. At the present day the help of the "stenter" is sought in any case, whether veterinary or otherwise, where it is required; and it is claimed, and indeed firmly believed in the district, that it is always successful. Two such cases were cited to me, one of a wounded horse, and the other of hæmorrhage from the lungs of a consumptive patient.

There are physical reasons, connected with the cessation of ill-directed attempts to staunch the bleeding during the absence of the messenger in search of the "stenter," which one could bring forward to account for the usual success of his charm; but they only accentuate the fact that his loss will be as great to the district as to the student of folk-lore. It may be added that the "stenter" does not visit the patient. The verse is openly pronounced wherever he may be working when found, and the assurance that it will be found effectual on the return of the messenger is added. The verse, which is the essential part of the charm, next to the personal element, was freely cominunicated to the doctor by the way; there being no "professional jealousy" in the matter on either side. ${ }^{1}$

Black Torrington still keeps up the ancient custom of "Skimmington riding," when some village scandal is to be held up to public reprobation. A very full and accurate description of such a function may be read in the Rev. S. Baring-Gould's Red Spider, the scene being laid in a village close at hand, and the ritual observed being that still in use. Notices for such a "meet of the stag-hounds," held in the spring of 1906 , were posted in places so far distant as Bideford, the route to be taken by the "hunt" being given in disguised writing. I myself saw the ride, but imperfectly, through the "dimpsies." 2 It was exactly the Red Spider episode, though the full details there given are perhaps collected from several occasions of the sort.

Akin to this expression of popular feeling on the subject of marital inconstancy is the old Essex custom of strewing chaff on the doorstep of a man who is known to have beaten his wife, in token that his "threshing" is public talk.

A milder hint of the same kind is the West Somerset

$$
{ }^{1} \text { C. ante. p. } 73 .
$$

Twilight. 
custom of displaying a broom over the door of a man whose wife is absent for what seems to the neighbours to be an unreasonable time. It is said to be "an advertisement for a housekeeper." A broom decorated with ribbons was found thus suspended over a door in Watchet, one morning in the spring of 1907 .

"Thicky Twelfth Night is not the hraight day for wassailing of the arpul-drees. Her should be doned on Old Twelfth Night, not on Old Christmas Day," said an ancient sage of Stockland in January 1908.

C. W. WhistLer.

Putting Life into an IDol.

(Communicated by Mr. G. H. Skipwith.)

"I was overcome with hunger when visiting a remote Buddhist temple [in China]... But an artist who was regilding the belly of the Buddha of the Future ... shared his meal with me. . . I I learnt from my friend and benefactor many curious facts as to idol-making. ...

"A conscientiously made idol is not complete when the outward form and features are finished. Bags of white and red silk representing the human intestines have to be put into the hollow of the body, and also packets of precious and mysterious substances. Then a living animal, such as a centipede or a mouse, is introduced and immured, so as to give life to the image. The eyes are left blank until the divinity has been placed in the position which he is going to occupy in the temple. Then the pupils are painted in, and the process of god-making, or deification, is complete." ("Letters from the Far East, No. II.," by Sir Charles Eliot, K.C.M.G.: Westminster Gazette, Nov. 27, 1906.) 